\title{
El racismo entra y sale de la escuela (EUNA, 2018), una obra de Jorge Ramírez-Caro
}

\section{Racism comes in and goes out of School (EUNA, 2018), a Book by Jorge Ramírez-Caro}

\section{$O$ racismo entra e sai da escola (EUNA, 2018), um livro de Jorge Ramírez-Caro}

Dra. Diana Senior-Angulo

Recibido: 15 de mayo, 2019

DOI: https: //doi.org/10.15359/tdna.35-65.19

No es la primera vez que se me invita y a la vez me siento convocada a presentar un libro de Jorge Ramírez-Caro. Quizás por mis intereses personales yacadémicos, aún sin leer la Introducción de su nueva obra, fui capaz de entender y validar el título del libro El racismo entra y sale de la escuela. El autor y yo ya tenemos unos años frecuentándonos en el ámbito académico. Sin embargo, no existe forma alguna de que pudiera haberme leído la mente, o la de personas académicas

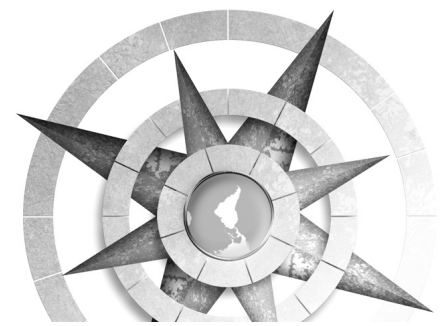

1 N.de E.: En Costa Rica se llama "niña" a las maestras de escuela primaria 
Los epígrafes de la obra de Caro Ramírez fueron muy bien escogidos, tanto, que podrían considerarse como un breve resumen de cada apartado; y, segmentados parcialmente se sostienen a través de conectores para consolidar el siguiente macro argumento:

“(...) La exposición y el desmantelamiento de las interpretaciones eurocéntricas es esencial si queremos comprender y cuestionar la distribución injusta de las relaciones del conocimiento 'legítimo' (...)", POR ELLO, “(...), En una sociedad de la información, trabajar con una única fuente informativa no tiene sentido, esto nos hace dogmáticos (...)", DE AHÍ QUE "Una de las tareas más importantes que tiene ahora la educación es enseñar con qué criterio juzgar la información (...)", PORQUE “(...) Lo que hubo fueron luchas terribles en las que las culturas autóctonas acabaron devastadas y sus portadores sometidos o aniquilados...” Y ES QUE “(...) [Nuestra historia] no nos llegó en capítulos, ni de menor a mayor, como suele suceder (...)”, MÁS BIEN “(...) El tratamiento de la diversidad cultural en los libros de texto está lejos de una perspectiva intercultural...”, YA QUE “(...) La hegemonía es creada y recreada por el cuerpo formal del conocimiento escolar, así como por las enseñanzas encubiertas que ha transmitido y sigue transmitiendo".

A partir de 1492, se dio comienzo a la invención de América, la cual, desde entonces, no ha dejado de ser reinventada al gusto y conveniencia de las élites políticas, económicas, intelectuales y religiosas de este y otros países del hemisferio. La nomenclatura que define y redefine a sus pobladores (los de viejo cuño y los de nueva incursión material) intenta simplificar la complejidad de las relaciones jerarquizantes que se decantan en favor de los autoproclamados "blancos" y la mayoría de sus privilegiados descendientes.

Por ello, la lectura y análisis del libro de Jorge Ramírez Caro que hoy presentamos nos ha sido sumamente útil, complementario y tuvo como espacio más que un epígrafe ayer, a propósito de un seminario que estamos impartiendo en la Universidad de Costa Rica, sobre Humanismo y migraciones internacionales, una mirada desde América Latina. Lo anterior, porque, precisamente, tanto en la ficción de las "razas" como en la construcción de distintas otredades, tenemos que llegar a comprender que es a partir de una matriz de poder hegemónico colonial y colonialista que nos han sido inculcados una serie de mitos en los que nos encontramos inmersos como sociedades y Estados nacionales, 
y que son precisamente estas representaciones las que terminan definiendo los lugares que grupos humanos, como ciertas nacionalidades migrantes, por ejemplo, deben pasar a ocupar dentro de los países receptores.

Desconozco cuál sea la pregunta coloquial que, desde el lugar común, se aborda a las poblaciones indígenas en cuanto a sus orígenes; pero, todavía a la altura de lo que llevamos recorrido del siglo XXI, de vez en cuando, alguna persona desconocida en la calle me pregunta: "Usted es de Limón, ¿verdad?" Y ante mi negativa, surge de inmediato, el "¡Ah, pero sí tiene familia allá!”, a lo que una plácida sonrisa de mi parte confirma lo que a la persona interlocutora parece tranquilizarle saber: por dónde entré a la nacionalidad costarricense; aunque, en mi caso, ese trazo identitario sea solamente parcial. En todo caso, de los imaginarios más fuertes que aún perviven en nuestras mentes, tenemos, con relación a los chinos, el que poco se quiera saber de ellos, que se asuma que no manejen el idioma español, y solo se les logra ubicar a cargo de restaurantes y establecimientos comerciales; pese a sus aportes, los cuales no se reducen al plano económico. Con relación a los indígenas, al imaginarlos con poco ropaje, en términos del sistemático despojo al que han sido sometidos, asumimos que no son dueños de nada y que, por tanto, no tienen posesiones; cuando muchos viven en las zonas más apetecidas por los intereses nacionales y transnacionales. Con relación a los afrodescendientes, el llevar una supuesta vida tranquila y hasta entretenida o de vacilón, vista desde afuera, niega a priori toda su historia marcada por la intensidad y el trabajo; codo a codo en la construcción del desarrollo nacional más allá de Limón, e hipotecado sucesivamente por los distintos gobiernos. Y en cuanto a las mujeres, prácticamente la mitad de la población, pese a los avances en términos de profesionalización y empoderamiento, aún siguen siendo relegadas, real, metafórica y simbólicamente, a tareas domésticas y de cuido, no deseadas por buena parte de ellas.

Y es que, en la problemática de la alteridad, podemos, de acuerdo con Todorov (1989, p. 195), distinguir al menos tres ejes: primero, la existencia de un juicio de valor (ya sea bueno o malo); segundo, el que se propicie un acercamiento o alejamiento (en términos de identificación con la otredad o asimilación de los mismos); y el tercero de los ejes nos sitúa frente a la disyuntiva de conocer o ignorar la identidad de esa "otredad". Por tanto, se hace evidente, a partir de los imaginarios que acabo de delinear, que, por lo menos, en cuanto a las poblaciones étnicamente diferenciadas se refiere, el relacionamiento de los demás hacia estas poblaciones ha sido canalizado más 
fácilmente en términos de alejamiento, invisibilización, así como juicios de valor negativos. Naturalmente, no tiene por qué seguir siendo así. Ramírez Caro subraya que

No sabemos qué piensan y qué tienen que decir los indígenas, los afrodescendientes, las mujeres y los campesinos sobre la dominación por condición étnico-cultural, genérica y clasista. Debemos luchar porque emerjan y reemerjan los saberes otros, invisibilizados y anulados por la colonialidad. Para eso debemos desengancharnos de la matriz de poder de la colonialidad (p. 69).

$\mathrm{Y}$ es a partir de un conocimiento que supere la mala intencionalidad de los sesgos propios de las dinámicas de enseñanza-aprendizaje que podremos asistir a un acercamiento de la realidad que nos retrate, no lo que a un pequeño grupo le interese mostrar, sino acercarnos a la aprehensión de una dignidad humana que trascienda la etnia, el género y la clase social.

Ramírez Caro tiene la habilidad, diría yo, de escribir de una manera ordenada y clara, misma que facilita la presentación secuencial de la información, datos y argumentos. De ahí que, mientras recorría sus páginas, indiscutiblemente quedó expuesta la forma en que los distintos textos analizados deciden colocar y conjugar, contenidos e imágenes, para configurar las relaciones de apropiación-identificación, versus rechazo-extrañamiento de lo observado y digerido por el estudiantado de manera sutil; situándonos, al mismo tiempo, frente a la realidad de un mundo que fabula una homogeneidad social armónica, bien lograda por parte de los autores intelectuales detrás de dichos textos; mismos que, en términos educativos, están llamados a formar y moldear las mentes, así como las actitudes de nuestra niñez costarricense.

En términos de estética y representación, nos demos cuenta o no, somos constantemente bombardeados con cánones que nos dictan lo que es aceptable y deseable socialmente; y cuando el público meta comprende entre los 6 y 12 años de edad, se les está imprimiendo además patrones conductuales que vehicularán su expresión, así como manifestación concreta, cuando el momento así se los demande: la programación a todas luces resulta efectiva.

Por ello, los fallos del currículo en materia de Estudios Sociales quedan patentes al permanecer, de manera soslayada, la idea de "razas" dentro de la conformación nacional, privilegiando ya no lo "blanco" directamente, sino lo mestizo, desde lógicas multiculturalistas pragmáticas. Lo mestizo alude a lo criollo y lo 
criollo, a lo europeo (español, concretamente en nuestra matriz colonizadora), de ahí que la mayoría continuará asumiéndose e identificándose desde las "bondades colonizadoras" y desde el lado de los "vencedores"; mientras que la "diversidad cultural" seguirá percibiéndose como nativa-ancestral (indígena) y "extranjera" bajo distintas causas (por parte de africanos, primero, afrocaribeños, después, y chinos, principalmente).

¿Por qué el racismo entra y sale de la escuela? Porque, de acuerdo con el autor, "Nadie nace racista. Se aprende a ser racista. En este proceso de aprendizaje intervienen la familia, la escuela, la comunidad, los medios masivos, la sociedad y la cultura en general" (p. 18). "En este marco, los textos escolares y la escuela cumplen un papel de primer orden en la formación y socialización de prejuicios, estereotipos y actitudes negativas de carácter étnico-cultural. Estas cogniciones sociales e ideológicas guardan una estrecha relación con el sexismo y el clasismo" (p. 19).

Afortunadamente, nos dice Mary Louise Pratt, «las voces críticas del asumido Tercer Mundo" empezaron a ser escuchadas... entraron los puntos de vista anclados en las colonias y excolonias, (mediante) perspectivas que cuestionaban los valores eurocéntricos y revelaban la fuerza que ejercieron el colonialismo y el imperio en la creación del mundo moderno» (Pratt, 2010, p. 31).
Aunque Ramírez Caro sea modesto en cuanto a su aporte, más allá del valioso insumo teórico y metodológico que nos presenta, dado el nivel de contribución que hace para la enseñanza-aprendizaje costarricense, este libro debería considerarse en primera instancia por los distintos centros educativos, su ente rector $\mathrm{y}$, además, ser canalizado a través de la Comisión $\mathrm{Na}$ cional de Estudios Afrocostarricenses del MEP; precisamente para honrar el cometido de su autor y "no seguir siendo indiferentes ante los problemas de la discriminación” (p. 20).

Ramírez Caro, además, recalca lo siguiente:

"Como niñas y niños son los principales destinatarios-usuarios de los textos escolares, necesitamos que sus docentes tengan buenas herramientas de análisis para que les ayuden a desmantelar las estrategias textuales y discursivas en las cuales se anclan los sesgos étnicoculturales, sexistas y clasistas, para que el aula se convierta en un espacio de lectura crítica y autocrítica de todo lo que los textos escolares digan y representen sobre hombres y mujeres, grupos étnico-culturales y grupos socioeconómicos" (p. 68).

Precisamente, hoy 15 de mayo, se conmemora el Día Internacional de la $\mathrm{Fa}$ milia, y curiosamente, las imágenes que 
circulan en las distintas redes sociales corresponden más a modelos nórdico-europeos que al retrato de una familia latinoamericana promedio o costarricense, inclusive. Efectivamente, todavía tenemos trabajo por delante. Trabajo reflexivo y crítico. Trabajo colectivo y proactivo, donde todas las partes puedan mirarse en el espejo de la patria y sentirse parte de esta gran nación. 